\title{
Transformation Methods of Production Organization from the Far East to the Metal Industry in Poland
}

Stanisław Borkowski, Paweł Szklarzyk, Krzysztof Knop

Institute of Engineering Production, Czestochowa University of Technology, Dąbrowskiego 69, 42-200 Częstochowa, Poland. E-mail: szklarzyk.paweł@o2.pl

\section{References}

[1] BORKOWSKI, S.(2012). Toyotarity. BOST method as the instrument of assessment process functioning according to Toyota principles. Faculty of Logistics. University of Maribor Publisher. Celje.

[2] BORKOWSKI, S. (2012). Zasady zarządzania Toyoty w pytaniach. Wyniki badań BOST. PTM Publisher. Warszawa.

[3] BORKOWSKI, S. (2012). Toyotaryzm. Wyniki badań BOST. PTM Publisher. Warszawa.

[4] BORKOWSKI, S., STASIAK-BETLEJEWSKA, R., NÁPRSTKOVÁ, N. (2011) The Kaizen philosophy in the aluminium products improvement. In: Manufacturing technology.Vol. 11, pp. 2-5. Czech Republic.

[5] BORKOWSKI, S., ULEWICZ, R. (2008). Zarzadzanie produkcja. systemy produkcyjne. Humanitas Publisher. Sosnowiec.

[6] DURLIK, I. (2007). Inżynieria zarządzania. Strategia i projektowanie systemów produkcyjnych cz. I. Placet Publisher. Warszawa.

[7] PN-EN ISO 9000:2006. Systemy zarządzania jakością. Podstawy i terminologia.

[8] KONSTANCIAK, M., BORKOWSKI, S., JAGUSIAK M. (2011). Supervisors' Assessment According to BOST Method in Chosen Polish Company. In: Communications. Vol. 4, pp. 58-62. Slovakia.

[9] LIKER, J. K. (2005). Droga Toyoty - 14 zasad zarządzania wiodącej firmy produkcyjnej świata. MT Biznes Publisher. Warszawa.

[10] Mario, F.C., Howell. G. (2012). Using production system design and Takt time to improve project performance. In: Conference paper: IGLC 2012 - 20th Conference of the International Group for Lean Construction.

[11] SZKLARZYK, P., KLIMECKA-TATAR, D., SYGUT, P. (2013). The meaning of "Toyotaryzm" in improving of the hot-rolled plates production process. In: Proceedings of Toyotarity. Management of the production values. (S. Borkowski, T. Grladinović (Ed.)), pp. 112-121. Savaş Kitap ve Yayınevi Publisher. Ankara, Türkiye.

[12] TAPPING, D., SHUKER, T. (2010). Zarzadzanie strumieniem wartości w biurze. Osiem etapów doskonalenia procesów biurowych. ProdPublishing.com. Wrocław.

[13] ULEWICZ, R. (2003). Quality control system in production of the castings from spheroid cast iron. In: Metalurgija. Vol. 42, Issue 1, pp. 61-63. Croatia. 